\title{
Potyvirus Complexes in Sweetpotato: Occurrence in Australia, Serological and Molecular Resolution, and Analysis of the Sweet potato virus 2 (SPV2) Component
}

\author{
Fred Tairo, Department of Plant Biology and Forest Genetics, Box 7080, SLU, SE-750 07 Uppsala, Sweden, and \\ Mikocheni Agriculture Research Institute, P.O. Box 6226, Dar-es-Salaam, Tanzania; Roger A. C. Jones, Agricultural \\ Research Western Australia, Locked Bag No. 4, Bentley Delivery Centre, Perth, WA 6983, and School of Biological \\ Sciences and Biotechnology, Murdoch University, Perth, WA 6150, Australia; and Jari P. T. Valkonen, Department \\ of Plant Biology and Forest Genetics, Box 7080, SLU, SE-750 07 Uppsala, Sweden, and Department of Applied Bi- \\ ology, P.O. Box 27, FIN-00014 University of Helsinki, Finland
}

\begin{abstract}
Tairo, F., Jones, R. A. C., and Valkonen, J. P. T. 2006. Potyvirus complexes in sweetpotato: Occurrence in Australia, serological and molecular resolution, and analysis of the Sweet potato virus 2 (SPV2) component. Plant Dis. 90:1120-1128.

A survey for viruses in sweetpotato revealed the presence of Sweet potato virus 2 (SPV2; synonymous to Sweet potato virus $\mathrm{Y}$ and Ipomoea vein mosaic virus), a tentative member of the genus Potyvirus, for the first time in Australia. The SPV2-infected sweetpotato plants were also infected with strains RC and/or C of Sweet potato feathery mottle virus (SPFMV; genus Potyvirus). Five SPV2 and SPFMV isolates from Australia were sequence-characterized at the $3^{\prime}$ proximal end (ca. $1.8 \mathrm{~kb}$ ) of the genome. A simple and sensitive diagnostic procedure was devised to readily differentiate SPV2 and the two strains of SPFMV from sweetpotato plants that contained these viruses in complexes. The method involved reverse transcription with oligo $T_{25}$ primer, polymerase chain reaction using a combination of degenerate primers, and restriction analysis of the $1.8 \mathrm{-kb}$ amplification products with HindIII and PvuII endonucleases. The Nproximal 543 nucleotides of the SPV2 coat protein-encoding sequence of the Australian isolates and 14 other isolates from Asia, Africa, Europe, and North America were subjected to phylogenetic analysis. The Australian SPV2 isolates formed a separate clade that was closest to a clade containing two North American isolates.
\end{abstract}

Additional keywords: Ipomoea batatas, IVMV, plant virus, RFLP, RT-PCR, SPVY

Sweetpotato (Ipomoea batatas) is an important root crop. It probably originated in Mexico and Central America but is now grown widely in Mediterranean-type, subtropical and tropical climatic regions of the world (35). Viruses are the most serious pathogens limiting its production worldwide (23), and several of these are potyviruses (genus Potyvirus, family Potyviridae). Of the sweetpotato potyviruses so far described (11), the most common worldwide is Sweet potato feathery mottle virus (SPFMV; synonyms Sweet potato russet crack virus, Sweet potato internal cork virus, Sweet potato A virus, Sweet potato chlorotic leafspot virus) (18). SPFMV is also the best characterized and consists of four strains that include RC (russet crack),

Corresponding author: Jari P. T. Valkonen

E-mail: jari.valkonen@helsinki.fi

Accepted for publication 4 April 2006.

DOI: 10.1094/PD-90-1120

(C) 2006 The American Phytopathological Society
C (common), O (ordinary) (24), and EA (East African) (22). RC and C are the most common worldwide, while EA is the least widely distributed. Strain $\mathrm{C}$ is the most divergent (1), showing only 76 to $82 \%$ nucleotide sequence identity for the coat protein (CP) cistron (34), which is at the species demarcation borderline for potyviruses (76 to $77 \%)(2,11)$. Its separation from the other SPFMV strains to form a separate virus, Sweet potato virus C, was proposed (34).

Much less is known about the other sweetpotato potyviruses. They include Sweet potato latent virus (SPLV) found in Asia, India, and Africa (23), Sweet potato mild speckling virus (SPMSV) from Argentina (10), and Sweet potato virus $G$ (SPVG) from China, Egypt, and the United States $(8,9,17,23,32)$. The potyviruses, tentatively named Ipomoea vein mosaic virus (IVMV) $(8,32)$ and Sweet potato virus Y (SPVY) (4), described in the United States and Africa, respectively, both represent the virus described originally as Sweet potato virus 2 (SPV2 or SPV-II) from Taiwan (25). Additional sequences of
SPV2 isolates (referred to as SPVY) from Nigeria (4), South Africa, Zambia, Portugal, and China have recently been deposited to the EMBL sequence database. Sweet potato vein mosaic virus (27) and a few additional, potentially distinct potyviruses (23) remain to be analyzed for their sequences.

Owing to relatively high levels of resistance to virus accumulation in many sweetpotato cultivars, virus titers are often low and direct virus detection from sweetpotato is unreliable using serological tests $(19,20)$. Therefore, grafting with Ipomoea setosa, a nearly universal host for sweetpotato viruses (5), is used to boost virus titer, and leaves of the grafted I. setosa are tested for viruses $(3,25,33)$. Reliable detection of potyviruses in sweetpotato is complicated further by frequent occurrence of mixed infections of potyvirus species, different strains of SPFMV, lack of antibodies that detect SPFMV strain $\mathrm{C}$ alone (26), and high-sequence homology between SPFMV strains RC, O, and EA (34). A simple and sensitive diagnostic procedure is needed to routinely and reliably differentiate potyviruses and SPFMV strains, especially from the potyvirus complexes that occur frequently in sweetpotato.

Australia has an important sweetpotato industry, but little is known about which viruses infect the crop. A simple healthy stock scheme relies on propagation from mother plants selected for health by graftinoculation with $I$. setosa scions. The plants are observed for virus symptoms, and any plants giving rise to symptoms are culled. No routine serological or nucleic acid-based tests for virus infections are done. Only SPFMV has been reported $(12,15)$, and strains RC and C of SPFMV have been differentiated (34).

The aim of this study was to test sweetpotato samples from three different locations to provide more information on the occurrence of SPFMV and its strains in Australia and to search for other viruses. Only SPFMV and SPV2 were found. A simple and sensitive diagnostic procedure 
involving restriction analysis of polymerase chain reaction (PCR) amplicons using two endonucleases was developed for rapid differentiation of the local potyvirus complexes in sweetpotato.

\section{MATERIALS AND METHODS}

Collection of samples. Sweetpotato material was collected from the state of Western Australia, which includes one-third of the Australian continent (Fig. 1). The sweetpotato industry is based in the Perth region in the southwest, the Carnarvon irrigation area in the central coastal region, and Broome and the Ord River Irrigation area (near Kununurra) in the remote Kimberley region in the tropical north.

A survey of sweetpotato plantings near Broome and Kununurra was made in 2004 (Fig. 1). In Broome, shoot samples were collected from farm 1 ( 2 crops, and a nursery used for cuttings), farm 2 (2 crops), and "organic" farm 3 (1 crop). For Kununurra, one crop was sampled at each of farms 4 to 6 . From each crop in both areas, shoots were collected at random, in addition to shoots from representative symptomatic plants. The shoots were transported to Perth in cooler boxes. On arrival, leaves were tested by enzymelinked immunosorbent assay (ELISA) (see below). Cuttings from the shoots were then planted in a glasshouse at ca. $25^{\circ} \mathrm{C}$. Those that rooted were grafted with $I$. setosa scions. The grafted plants and scions were observed for viral symptoms. After 3 to 4 weeks, leaf tissue from the I. setosa scions was tested by ELISA. Although no aphids were observed in the glasshouse and there was no evidence of plant-to-plant spread of viruses, insecticides were applied regularly.

In Perth, six separate batches of two to eight sweetpotato roots were purchased from supermarkets, including one batch of cv. Northern Star and five batches of cv. Beauregard. The tuberous roots were planted in growth cabinets or a glasshouse $\left(25^{\circ} \mathrm{C}\right)$. The plants were observed for viral symptoms. Leaves from each plant were tested for viruses by ELISA (described below).

Serological assays. J. Vetten, Institute for Plant Virology, Braunschweig, Germany, kindly supplied virus-specific polyclonal antibodies and enzyme conjugates to SPV2, SPVG, SPLV, and Sweet potato chlorotic fleck virus (SPCFV) for use in double antibody sandwich ELISA (DASELISA), and IgG and monoclonal antibodies to SPFMV, Sweet potato mild mottle virus (SPMMV), and East and West African strains of Sweet potato chlorotic stunt virus (SPCSV) for use in triple antibody sandwich ELISA (TAS-ELISA). Optimum antibody and enzyme conjugate dilutions were made as recommended by J. Vetten. Polyclonal antibodies and enzyme conjugate to Cucumber mosaic virus (CMV) for use in DAS-ELISA were purchased from
Löwe Biochemica (Sauerlach, Germany). Positive control cultures were available locally in Australia for SPFMV and CMV, but not to the other sweetpotato viruses. To test samples of sweetpotato or I. setosa leaf tissue by DAS-ELISA and TASELISA in microplates, the procedures followed were as described previously $(3,14,16)$. Absorbance values were recorded at $405 \mathrm{~nm}\left(A_{405}\right)$. Readings at least three times the values of the negative control samples were considered positive.

For nitrocellulose membrane ELISA (NCM-ELISA), a test kit with polyclonal antibodies to SPFMV, SPCFV, SPLV, SPVG, SPMMV, SPCSV, virus C-6, Sweet potato caulimo-like virus, and SPMSV together with NCM test strips spotted with sap from virus-positive and noninfected control plants were kindly supplied by $\mathrm{S}$. Fuentes, International Potato Center (CIP), Lima, Peru. To test leaf tissue samples by NCM-ELISA, the protocol supplied with the CIP test kits was followed and visual assessment for color in the blots was used to identify virus-positive samples.

PCR amplification and cloning. Total RNA was extracted from $200 \mathrm{mg}$ of symptomatic sweetpotato leaf tissue using TRizol reagents according to manufacturer's instructions (Life Technologies Inc., Grand Island, NY). cDNA was synthesized on 3 $\mu \mathrm{g}$ of total RNA by reverse transcription (RT) using an oligo-d $\mathrm{T}_{25}$ primer and $3 \mu \mathrm{l}$ of the reaction used as a template for PCR (total reaction volume $50 \mu \mathrm{l}$ ) as described (33). Viral sequences were amplified by PCR using procedures described by IsHak et al. (17), including a forward degenerate primer (PVD-2) complementary to the conserved GNNSGQ motif-encoding se-

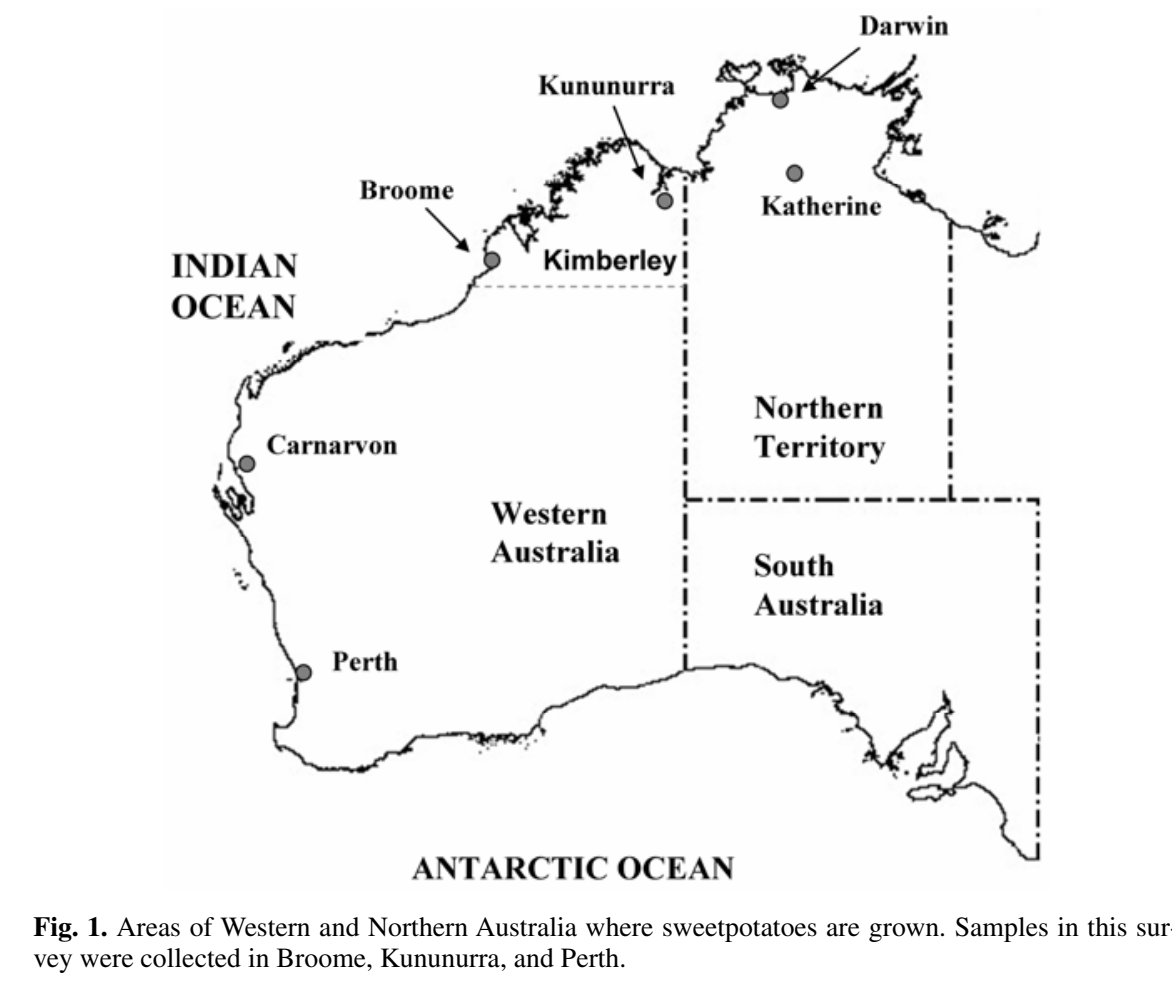

Fig. 1. Areas of Western and Northern Australia where sweetpotatoes are grown. Samples in this survey were collected in Broome, Kununurra, and Perth. quence in the NIb region of the Potyviridae (13) and a reverse primer (10820R) complementary to $3^{\prime}$ end of the nontranscribed region (NTR) of viruses of the genus Potyvirus (34). In addition, sequences of SPV2 were amplified using a virus-specific forward primer (SPV2) (4) and reverse primer 10820R (Table 1). SPFMV strain C was differentiated by RT-PCR using forward primer SPVC712 and reverse primer SPVC343 (designed in this study), which resulted in an amplicon of ca. $270 \mathrm{bp}$ (Table 1$)$. PCR products $(10 \mu \mathrm{l})$ were analyzed by electrophoresis in a $1 \%$ agarose gel, visualized under UV light, and the sizes estimated by comparison with a DNA size marker (MBI Fermentas, Vilnius, Lithuania).

For sequencing, PCR amplicons were purified from the gel, ligated into the TOPO TA pCR II vector (Invitrogen, Groningen, The Nertherlands), and transformed to Escherichia coli $\mathrm{TOP} 10 \mathrm{~F}^{\prime}$ cells following standard procedures (30). Clones were sequenced using universal primers designed according to the plasmid sequence and subsequently with nested primers designed for the viral sequences. Both strands of two independently amplified fragments were sequenced for each Sequencing was done using the DYEnamic ET Terminator Cycle Sequencing Kit (Amersham Pharmacia Biotech AB, Uppsala, Sweden), and reactions were analyzed with an automated ABI Prism 377 DNA sequencer (Perkin-Elmer, Applied Biosystems, Foster City, CA).

Sequence analyses. Multiple sequence alignments representing the 3 '-proximal genomic regions of potyviruses were conisolate to obtain a consensus sequence. 
structed using CLUSTAL W option of the MEGALIGN program (Lasergene software, DNAStar ver.5.03, 2001). Additional viral sequences were obtained from the EMBL/GenBank database. Sequences were examined both visually and using the computer program SeqMan (DNAStar, Madison, WI). To accommodate two SPV2 isolates (LSU-2 and LSU-5) with only partial CP sequence available, percent nucleotide (nt) and amino acids (aa) were calculated using two data sets, including the complete (996 nt) and partial N-proximal (543 nt) CP-encoding sequences, and the corresponding deduced aa sequences. Phy- logenetic distances were calculated with Distance program (DNADIST) using Kimura two-parameter model (21). Two phylogenetic trees were constructed by neighbor-joining method (NEIGHBOR) of PHYLIP Package using the aforementioned two data sets. Bootstrapping was done 1,000 times by SEQBOOT for estimation of stability and support for the inferred branches. The TREEVIEW program (version 1.6.5) was used to draw the resulting tree.

Restriction fragment length polymorphisms (RFLP) analysis. Sequences corresponding to the $1.8-\mathrm{kb}$ amplicon ob-

Table 1. Primers used for amplification of potyvirus sequences

\begin{tabular}{|c|c|c|c|}
\hline Virus $^{\mathbf{a}}$ & $\begin{array}{l}\text { Primer } \\
\text { name }\end{array}$ & Sequence & Reference \\
\hline \multicolumn{4}{|c|}{ SPFMV and SPV2: } \\
\hline Forward & PVD-2 & 5'-GGBAAYAAYAGYGGDCARCC-3' & (13) \\
\hline Reverse & 10820R & 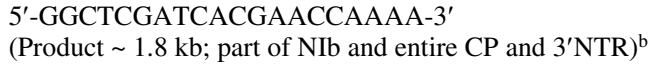 & (34) \\
\hline \multicolumn{4}{|c|}{ SPFMV, strains RC and $\mathrm{EA}^{\mathrm{c}}$ : } \\
\hline Forward & FM1360 & 5'-GACCAAGCCCCATACAATGA-3' & This study \\
\hline Reverse & 10820R & $\begin{array}{l}\text { (see above) } \\
\left.\text { (Product } \sim 1.3 \mathrm{~kb}: 168 \mathrm{nt} \text { NIb, } 945 \mathrm{nt} \mathrm{CP}, 221 \mathrm{nt} 3^{\prime} \mathrm{NTR}\right)\end{array}$ & \\
\hline Forward & FM1360 & (see above) & \\
\hline Reverse & UTR34 & $\begin{array}{l}\text { 5'-TTAAAGGCATACTAAAGATAA-3' } \\
\text { (Product } \sim 1.2 \mathrm{~kb}: 168 \mathrm{nt} \mathrm{NIb}, 945 \mathrm{nt} \mathrm{CP}, 54 \mathrm{nt} 3^{\prime} \mathrm{NTR} \text { ) }\end{array}$ & $(22)$ \\
\hline \multicolumn{4}{|c|}{ SPFMV, strain C: } \\
\hline Forward & SPVC474 & 5'-CAGTGAACTAGCACGAAC-3' & This study \\
\hline Reverse & $10820 \mathrm{R}$ & $\begin{array}{l}\text { (see above) } \\
\text { (Product } \sim 1.3 \mathrm{~kb}: 168 \mathrm{nt} \text { NIb, } 939 \text { nt CP, } 221 \text { nt 3'NTR) }\end{array}$ & \\
\hline Forward & SPVC712 & 5'-TATACAGCACCAGAAATCA-3' & This study \\
\hline Reverse & SPVC343 & $\begin{array}{l}\text { 5'-GGTGTTGTAAGTTTACTACA-3' } \\
(270 \mathrm{bp}, \mathrm{CP})\end{array}$ & This study \\
\hline $\begin{array}{l}\text { SPV2: } \\
\text { Forward } \\
\text { Reverse }\end{array}$ & $\begin{array}{l}\text { SPV2 } \\
10820 \mathrm{R}\end{array}$ & $\begin{array}{l}\text { 5'-CGAACTTGCTCGAGTAGGCAG- 3' } \\
\text { (see above) } \\
\text { (Product } \sim 1.4 \mathrm{~kb}: 168 \mathrm{nt} \text { NIb, } 996 \mathrm{nt} \mathrm{CP}, 216 \mathrm{nt} \text { 3'NTR) }\end{array}$ & (4) \\
\hline
\end{tabular}

a SPFMV, Sweet potato feathery mottle virus; SPV2, Sweet potato virus 2.

b Genomic regions amplified: NIb, replicase encoding sequence; $\mathrm{CP}$, coat protein encoding sequence; $3^{\prime} \mathrm{NTR}, 3^{\prime}$-nontranslated sequence.

c These primers do not distinguish SPFMV strains RC and EA, and may also amplify strain O (not tested). tained with primers PVD-2 and 10820R (Table 1) from SPFMV and SPV2 were analyzed to select endonucleases predicted to result in distinguishable restriction fragments readily resolvable by agarose gel electrophoresis. Searching for discriminating restriction sites was by the computer program Vector NTI suite 8 (Infomax, WI).

For RFLP analysis, PCR products (40 $\mu \mathrm{l})$ were precipitated with $15 \mu \mathrm{l}$ of $3 \mathrm{M}$ sodium acetate and $150 \mu \mathrm{l}$ of $95 \%$ ethanol. The precipitates were spun at $10,000 \times g$ for $15 \mathrm{~min}$. The pellet was washed with $250 \mu \mathrm{l}$ of $70 \%$ ethanol, followed by spinning at $10,000 \times g$ for $10 \mathrm{~min}$. The supernatant was discarded and the pellet briefly air-dried and finally resuspended in $50 \mu \mathrm{l}$ of RNase-free water. An aliquot (10 $\mu \mathrm{l})$ of the DNA was digested with HindIII or $P v u \mathrm{II}$ (MBI Fermentas) at $37^{\circ} \mathrm{C}$ overnight according to the manufacturer's instructions. Restriction patterns were revealed by electrophoretic separation in a $1.6 \%$ agarose gel at $80 \mathrm{~V}$ for $3 \mathrm{~h}$.

\section{RESULTS}

Serological detection of viruses. The sweetpotato crops at Broome (West Kimberley) and Kununurra (East Kimberley) were inspected in the field for viruslike symptoms and recorded (Table 2). Symptomatic plants were observed in four of seven field crops, a nursery for sweetpotato cuttings, and in volunteer sweetpotato plants in the field. Incidences of plants with symptoms varied widely (Table 2 ). SPFMV was detected in sweetpotatoes from two of the three farms at Broome and from two of the three farms at Kununurra. At farm 4 in Kununurra, SPFMV was still detected despite the absence of symptomatic plants in the crop. Infections with SPFMV were detected in more plants by testing leaves from I. setosa scions grafted

Table 2. Occurrence of virus infection in sweetpotatoes in the Kimberley region of northwest Australia

\begin{tabular}{|c|c|c|c|c|c|c|c|c|}
\hline \multirow[b]{3}{*}{ Farm } & \multirow[b]{3}{*}{ Shoots from } & \multirow[b]{3}{*}{ Cultivar } & \multirow{3}{*}{$\begin{array}{l}\text { Plants (\%) with } \\
\text { symptoms }\end{array}$} & \multirow{3}{*}{$\begin{array}{l}\text { Types of } \\
\text { symptoms }\end{array}$} & \multicolumn{4}{|c|}{ Viruses detected in shoots randomly collected from field ${ }^{a}$} \\
\hline & & & & & \multicolumn{2}{|c|}{ From sweetpotato leaves } & \multicolumn{2}{|c|}{$\begin{array}{l}\text { From scions of Ipomoea setosa } \\
\text { grafted on rooted shoots }\end{array}$} \\
\hline & & & & & SPFMV & SPV2 & SPFMV & SPV2 \\
\hline \multicolumn{9}{|l|}{ Broome } \\
\hline \multirow[t]{3}{*}{1} & Crop & Northern Star & None & - & $0 / 11^{\mathrm{c}}$ & $0 / 11$ & $0 / 10$ & $0 / 10$ \\
\hline & Crop & Beerwah Gold & None & - & $0 / 11$ & $0 / 11$ & $0 / 11$ & $0 / 11$ \\
\hline & Nursery & Beerwah Gold & Trace & $\mathrm{CR}, \mathrm{CLP}$ & $0 / 10$ & $0 / 10$ & $0 / 10$ & $0 / 10$ \\
\hline \multirow[t]{2}{*}{2} & Crop & Jewel & c. 20 & PRS & $2 / 6$ & $3 / 6$ & $2 / 5$ & $2 / 5$ \\
\hline & Volunteers & Unknown & 100 & $\mathrm{P}, \mathrm{Dw}$ & $0 / 5$ & $0 / 5$ & $0 / 5$ & $0 / 5$ \\
\hline 3 & Organic crop & Beerwah Gold & c. 50 & $\mathrm{P}, \mathrm{Dw}$ & $0 / 10$ & $0 / 10$ & $7 / 7$ & $0 / 7$ \\
\hline \multicolumn{9}{|l|}{ Kununurra } \\
\hline 4 & Crop & Beauregard & None & - & $0 / 7$ & $0 / 7$ & $3 / 5$ & $0 / 5$ \\
\hline 5 & Crop & Beauregard & Trace & $\begin{array}{l}\text { M, LD, P, } \\
\text { VC, DW }\end{array}$ & $2 / 7$ & $0 / 7$ & $4 / 7$ & $0 / 7$ \\
\hline \multirow[t]{2}{*}{6} & Crop & Unknown & None & - & $0 / 6$ & $0 / 6$ & $0 / 5$ & $0 / 5$ \\
\hline & & & & Total: & $4 / 76$ & $3 / 6$ & $16 / 65$ & $2 / 65$ \\
\hline
\end{tabular}

a Plants were tested for 11 viruses by double antibody sandwich (DAS-) and/or nitrocellulose membrane (NCM-) enzyme-linked immunosorbent assay (ELISA). Only Sweet potato feathery mottle virus (SPFMV) and Sweet potato virus 2 (SPV2) were detected.

${ }^{\mathrm{b}} \mathrm{CR}$, chlorotic rings; CLP, chlorotic line patterns; PRS, purple ring spots; M, mottle; LD, leaf deformation; VC, vein clearing; P, pallor; DW, plant dwarfing. Note: VC, P, and DW are symptoms often associated with sweet potato little leaf phytoplasma (unpublished data).

${ }^{\mathrm{c}}$ Number of ELISA-positive shoots (scions) per the total number tested. 
onto cuttings than directly from sweetpotato leaves. The only other virus found was SPV2, which was present with SPFMV in the symptomatic plants of cv. Jewel in farm 2 at Broome. The cultivars infected were Beauregard, Beerwah Gold (SPFMV only), and Jewel (both viruses). Cuttings of two plants of Jewel (coded 55-4 and 55-6) positive for SPV2 and SPFMV and one plant of Beauregard (120-7) positive for SPFMV were chosen and the viruses in them subjected to molecular analyses.

Plants infected with both SPFMV and SPV2 or SPFMV alone often became symptomatic in their lower leaves when grown under glasshouse conditions. Plants of cv. Jewel infected with both viruses developed obvious chlorotic leaf spots, rings and blotching, and vein banding (Fig. 2A). Plants of cv. Beauregard (Fig. 2B) and Beerwah Gold (Fig. 2C) infected with SPFMV showed transient chlorotic spotting or blotching. I. setosa scions growing on virus-infected plants developed a range of symptoms including vein clearing, chlorotic spotting and blotching, mottle, vein banding, and leaf deformation.

All 18 sweetpotato plants of cv. Beauregard and two of cv. Northern Star grown from five lots and one lot, respectively, of tuberous roots purchased from supermarkets in Perth showed viruslike symptoms on their lower leaves. These often transiently expressed symptoms consisted of mottle and rugosity or chlorotic blotches and rings in Beauregard, and chlorotic blotches and rings in Northern Star. ELISA revealed SPFMV in leaf samples from all eight sweetpotato plants belonging to three of the six batches of Beauregard and in one of two plants of cv. Northern Star. Both Northern Star plants tested positive for SPV2. Presence of SPFMV in one and SPV2 in both Northern Star plants was confirmed by ELISA on leaf samples from I. setosa scions grafted onto each of the plants. Cuttings from these two plants were designated Pink1 and Pink2, and the viruses were subjected to PCR amplification and sequence analysis. No other virus was detected in the plants tested from
Perth. However, as SPFMV strain C was not detectable with the antibodies used, it remained a possible cause of the symptoms in the plants in which no virus was detected by serological assays.

Analysis of SPFMV sequences. The 3'proximal part of genomic sequence of five SPFMV isolates was cloned from seropositive plants, sequenced, and the sequences deposited in the EMBL sequence databank (Table 3). Phylogenetic analysis of $\mathrm{CP}$ encoding sequences of these isolates and those available in sequence databanks was used to identify SPFMV strain groups including the Australian RC isolates Aus2 and Aus6, and $\mathrm{C}$ isolates Aus4 and Aus5 sequence-characterized previously (34). Plants of cv. Beauregard from different farms near Kununurra were found to be coinfected with SPFMV strains RC and $\mathrm{C}$ (isolates Aus142-ARC and Aus142-AC, respectively) or RC alone (isolate Aus1207). Strain C (isolate Aus55-4C) was detected in plants of cv. Jewel from Broome and cv. Northern Star from Perth (isolate Pink-2C) (Table 3).
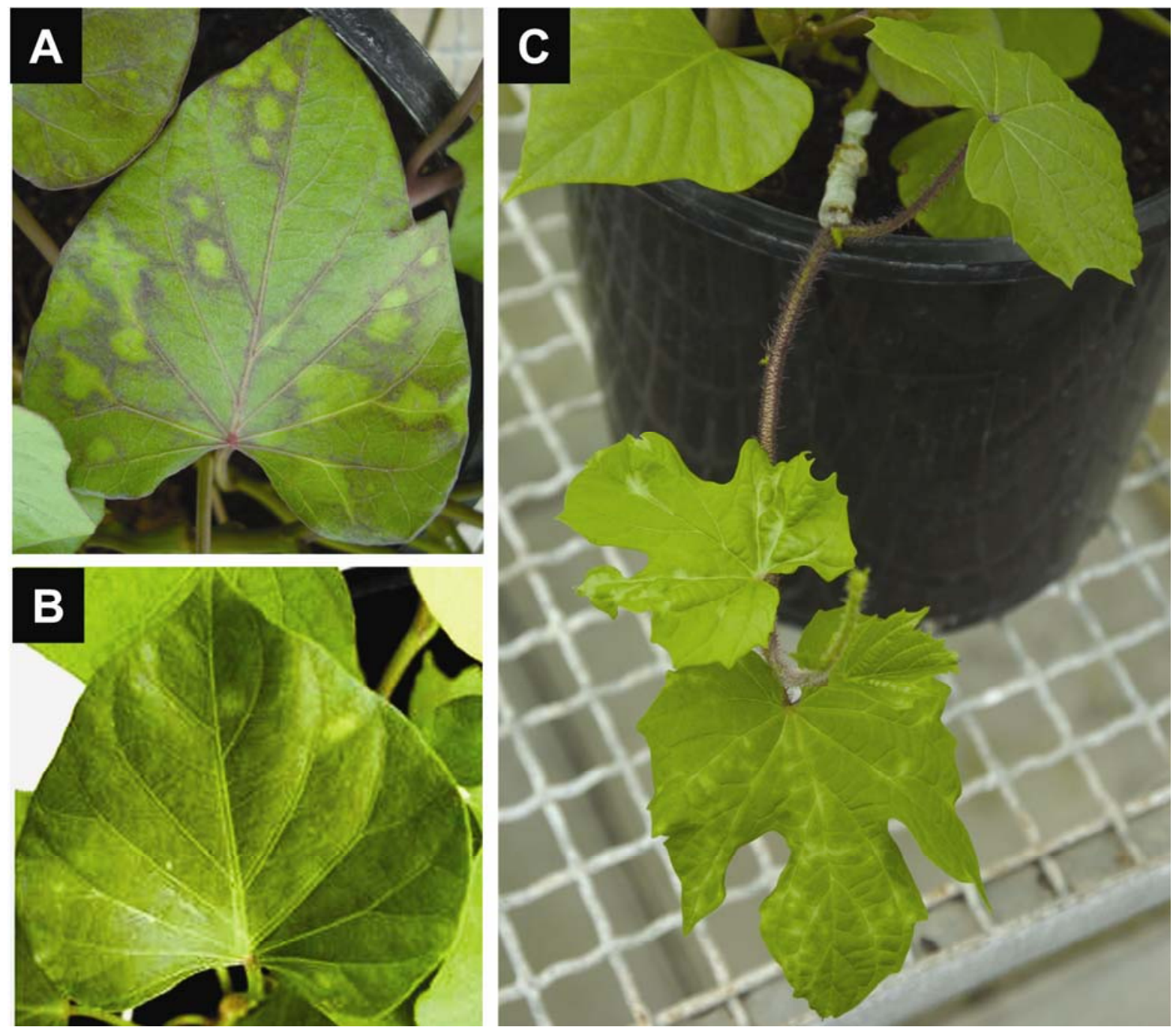

Fig. 2. Virus-associated symptoms in sweetpotato leaves. A, Chlorotic spots with red borders (ring spots) following systemic triple-infection of cv. Jewel with Sweet potato virus 2 (SPV2) and Sweet potato feathery mottle virus (SPFMV) strains RC and C. B, Mild chlorotic spotting in systemically infected leaves of cv. Beauregard infected with SPFMV. C, Systemic vein clearing and chlorotic vein banding in an Ipomoea setosa scion infected by grafting onto sweetpotato cv. Beerwah Gold infected with SPFMV. 
Analysis of SPV2 sequences. The 3'proximal sequences of five SPV2 isolates from sero-positive plants were cloned by RT-PCR and sequenced. Isolate Pink1 was amplified using primers PVD-2 (forward) and 10820R (13), which resulted in a product of 1,857 nt. For isolates Aus54, 554, 55-6, and Pink2, forward primer SPV2 (4) was used instead of PVD-2, resulting in a product of $1,381 \mathrm{nt}$. These amplification products included $645 \mathrm{nt}$ or $168 \mathrm{nt}$ of NIbencoding sequence, respectively, the $\mathrm{CP}$ cistron (996 nt), and the 3'NTR (216 nt, excluding the poly(A) tail). Deduced amino acid sequences revealed the $\mathrm{NIb} / \mathrm{CP}$ proteolytic cleavage site and the Asp-Ala-Gly (DAG) motif required for potyvirus transmission by aphids (31) at the same position in the Australian SPV2 isolates and those available from other countries (Table 3 ).

Pairwise comparison of the complete $\mathrm{CP}$-encoding sequences between the Aus- tralian isolates of SPV2 revealed high $\mathrm{nt}$ (99.4 to $99.9 \%)$ and aa (97.4 to $99.7 \%$ ) identities. Isolates Aus54, Aus55-4, and Aus55-6 obtained from different plants of the same crop of cv. Jewel at Broome were essentially identical $(99.9 \%)$ at nt level. Similarly, Pink1 and Pink2 cloned from two different plants of the same lot of sweetpotato roots (cv. Northern Star) from Perth had $99.5 \%$ nt identity. Plants infected with Aus55-4 and Pink2 were co-infected with SPFMV strain C (isolates Aus55-4C and Pink-2C, respectively; Table 3 ).

Comparisons between the five Australian SPV2 isolates and sequences from 13 SPV2 isolates from other parts of the world (Table 3) were done initially using complete $\mathrm{CP}$ encoding sequences, but because only the N-proximal 543 nt were available for two isolates LSU-2 and LSU5 from the United States, the data in Table 4 are based on partial sequences. In terms of sequence identities, the isolate groupings using the complete and partial sequences were, however, similar. Isolates LSU-2 and LSU-5 (98.5 to 99.1\%) and the three isolates from Portugal (97.1 to 97.4\%) were closest to the Australian isolates in nt and aa sequence identity ( 97.8 to $98.9 \%$ and 95.6 to $97.2 \%$, respectively). Isolate SPV2-Zambia (Table 4) was the most divergent (74.4 to $77.0 \%$ and 76.8 to $80.1 \%$ identical at nt and aa levels, respectively). The nt and aa identities among other isolates were $>90 \%$ (Table 4). The $\mathrm{CP}$ aa sequence of isolate Thomas16A (from South Africa) showed high identity (>90\%) to other isolates, but the nt sequence was less identical (82.9 to $85.6 \%$ ), indicating many silent $\mathrm{nt}$ substitutions in the $\mathrm{CP}$ encoding region. Indeed, most of the substitutions were at the third codon position. The 19 SPV2 isolate sequences were closest to SPFMV-Zw (64.1 to $66.5 \%$

Table 3. Virus isolates from this study and sequences retrieved from the databank

\begin{tabular}{|c|c|c|c|c|}
\hline $\begin{array}{l}\text { Virus species } \\
\text { Isolate }\end{array}$ & Strain & Geographical origin & Accession no. & Reference \\
\hline \multicolumn{5}{|l|}{ SPV2 } \\
\hline $260702 / 1$ & & Portugal & AY459614 & E. M. Ateka, 2003 unpublished \\
\hline $300902 / 31$ & & Portugal & AY459613 & E. M. Ateka, 2003 unpublished \\
\hline Aus54 & & Broome, W Kimberley, Australia & AM050884 & This study \\
\hline Aus55-4 & & Broome, W Kimberley, Australia & AM050885 & This study \\
\hline Aus55-6 & & Broome, W Kimberley, Australia & AM050886 & This study \\
\hline J51 & & S Africa & AY459603 & E. M. Ateka, 2003 unpublished \\
\hline Lourol & & Portugal & AY459604 & E. M. Ateka, 2003 unpublished \\
\hline LSU-2 & & USA & AY178992 & 32 \\
\hline LSU-5 & & USA & AY178989 & 32 \\
\hline MD2 & & S Africa & AY459606 & E. M. Ateka, 2003 unpublished \\
\hline MD521 & & S Africa & AY459605 & E. M. Ateka, 2003 unpublished \\
\hline Nigeria $\left(\right.$ SPV2) ${ }^{\mathrm{a}}$ & & Nigeria & AY232437 & 4 \\
\hline PD12 & & S Africa & AY459607 & E. M. Ateka, 2003 unpublished \\
\hline Pink1 & & Perth, SW Australia & AM050887 & This study \\
\hline Pink2 & & Perth, SW Australia & AM050888 & This study \\
\hline Thomas16A & & S Africa & AY459608 & E. M. Ateka, 2003 unpublished \\
\hline TschilomboIV-1 & & S Africa & AY459612 & E. M. Ateka, 2003 unpublished \\
\hline VTSBTschilombo & & S Africa & AY459609 & E. M. Ateka, 2003 unpublished \\
\hline $\mathrm{XN} 3$ & & China & AY459611 & E. M. Ateka, 2003 unpublished \\
\hline Zambia & & Zambia & AY459610 & E. M. Ateka, 2003 unpublished \\
\hline \multicolumn{5}{|l|}{ SPFMV } \\
\hline Apa & EA & Apachi, Uganda & AJ781787 & 34 \\
\hline Aus120-7 & $\mathrm{RC}$ & Kununurra, E Kimberley, Australia & AM050889 & This study \\
\hline Aus142-ARC & $\mathrm{RC}$ & Kununurra, E Kimberley, Australia & AM050890 & This study \\
\hline Aus142-AC & $\mathrm{C}$ & Kununurra, E Kimberley, Australia & AM050891 & This study \\
\hline Aus2 & $\mathrm{RC}$ & Perth, SW Australia & AJ 781775 & 34 \\
\hline Aus4 & $\mathrm{C}$ & Perth, SW Australia & AJ781778 & 34 \\
\hline Aus5 & $\mathrm{C}$ & Perth, SW Australia & AJ781779 & 34 \\
\hline Aus55-4C & $\mathrm{C}$ & Broome, W Kimberley, Australia & AM050892 & This study \\
\hline Aus6 & $\mathrm{RC}$ & Perth, SW Australia & AJ781777 & 34 \\
\hline Bag & EA & Bagamoyo, Tanzania & AJ781780 & 34 \\
\hline Bkb2 & EA & Bukoba, Tanzania & AJ781782 & 34 \\
\hline Bny & EA & Bushenyi, Uganda & AJ539130 & 34 \\
\hline Can3 & EA & Canary, Portugal & AY459600 & E. M. Ateka, 2003 unpublished \\
\hline $\mathrm{CH}(\mathrm{Zh})$ & $\mathrm{RC}$ & Zhejiang, China & AJ310202 & 7 \\
\hline Kenya24/4A & $\mathrm{C}$ & Kenya & AY523543 & E. M. Ateka, 2003 unpublished \\
\hline $\mathrm{Mbl2}$ & EA & Mbale, Uganda & AJ781788 & 34 \\
\hline Mpg2 & EA & Mpigi, Uganda & AJ781789 & 34 \\
\hline Nak & EA & Nakasongola, Uganda & AJ781790 & 34 \\
\hline Pink-2C & $\mathrm{C}$ & Perth, SW Australia & AM050893 & This study \\
\hline $\mathrm{S}$ & $\mathrm{RC}$ & Japan & D86371 & 29 \\
\hline Sor & $\mathrm{C}$ & Soroti, Uganda & AJ539129 & 25 \\
\hline SPFMV-Zw & Unknown & Zimbabwe & AF016366 & 6 \\
\hline Tz2 & EA & Bagamoyo, Tanzania & AJ539132 & 26 \\
\hline Unj1 & EA & Unguja, Tanzania & AJ781786 & 34 \\
\hline
\end{tabular}

a The geographic origin of this isolate is unknown. See Ateka et al. (4). E, East; S, South; W, West. 
and 54.7 to $60.2 \% \mathrm{nt}$ and aa identity, respectively) (Table 4) and less identical to other SPFMV isolates.

Phylogenetic analysis based on $543 \mathrm{nt}$ of the CP-encoding sequences revealed three groups of SPV2 isolates supported by high bootstrap values (Fig. 3). The five Australian isolates formed a uniform group separated from the others. Three South African isolates (J51, M521, and PD12) formed the second group. The third group consisted of the two American and three Portuguese isolates, South African isolate TschilomboIV-1, and the isolates designated as $\mathrm{Ni}$ geria (geographic origin unknown) and XN3 (China). The remaining three South African SPV2 isolates and single Zambian isolate did not fit into any of the three phylogenetic groups.

Restriction analysis of viral amplification products. Serological detection and sequence-characterization of viruses indicated that mixed infection with SPV2 and SPFMV strains $\mathrm{RC}$ and $\mathrm{C}$ is common in Australian sweetpotatoes. As expected, RTPCR amplification using the degenerate potyvirus-specific primers PVD-2 and 10820R amplified a product of ca. $1.8 \mathrm{~kb}$ from all samples that were positive for SPFMV or SPV2 (representative examples displayed in Figure 4, panel "RT-PCR"). Amplification was also obtained from some plants that were sero-negative but infected with SPFMV strain C that was not serologically detectable. Viral sequences from this study and those available from databanks were analyzed to identify restriction sites for endonucleases that could be used alone or in combination to characterize the RT-PCR amplification products and hence identify the different viruses and virus strains from mixtures. Restriction analysis of the amplicon of SPFMV strain RC with HindIII resulted in two fragments ( 1.3 and $0.5 \mathrm{~kb}$ ) detectable by agarose gel electrophoresis, whereas the amplicons of
SPFMV strain C and SPV2 were not restricted. In contrast, $P v u I I$ generated distinct restriction fragments from SPFMV strain C (1.4 and $0.4 \mathrm{~kb})$ and SPV2 (1.3 and $0.5 \mathrm{~kb}$ ), but did not cleave the SPFMV strain RC amplicon.

Restriction analysis was tested on samples of virus-infected sweetpotato plants from Australia, with one Ugandan sweetpotato plant infected with SPFMV-C as a control. The analysis is exemplified with seven samples in Figure 4. Analysis with HindIII resulted in restriction fragments in six samples (lanes 2 to 4 and 6 to 8; Fig. 4), suggesting that plants were infected with SPFMV strain RC. However, in all samples except one (no. 4), some of the $1.8-\mathrm{kb}$ amplification product remained unrestricted, which suggested that they contained SPFMV strain C and/or SPV2. When the same samples were analyzed with $P v u \mathrm{II}$, the 1.4-kb fragment diagnostic to SPFMV strain $\mathrm{C}$ was generated in samples 1 and 4 to 8 , whereas the $1.3-\mathrm{kb}$ fragment diagnostic to SPV2 was obtained with samples 5, 7, and 8 (Fig. 4). Lack of restriction with $P v u I I$ for the amplicons in samples 2 and 3 indicated that SPFMV strain C and SPV2 were absent. These data were interpreted as follows: plant 1 from Uganda was infected with SPFMV-C as expected; plants 2 and 3 were infected only with SPFMV-RC (the traces of the RT-PCR product left following treatment with HindIII in sample 2 in this particular case were due to incomplete enzyme digestion); plants 4 and 6 were co-infected with SPFMV strains RC and C; plant 5 was co-infected with SPFMV-C and SPV2; and plants 7 and 8 were co-infected with all three viruses (Fig. 4). The data were consistent with the serological detection of SPFMV (reveals SPFMV-RC) in plants 2 to 4 and 6 to 8 , and SPV2 in plants 5, 7, and 8. Importantly, RT-PCR and restriction analysis detected SPFMV-C in six of the eight plants tested, which could not be revealed by serological means. Plants 1 (control), 4, 5, and 6 were also tested by RT-PCR using the SPFMV-C specific primers: the products were sequenced and the presence of SPFMV-C was verified.

\section{DISCUSSION}

Our survey involved many samples collected from sweetpotato crops at two isolated locations in tropical northwest Australia and from roots obtained at supermarkets in Perth in the Mediterranean-type climatic region of southwest Australia. Some of the latter may have originated in Queensland in northeast Australia where there is a large sweetpotato industry, but most were from the state of Western Australia. The survey revealed the presence of SPV2 for the first time in Australia. Sweetpotato plants infected with SPV2 often displayed obvious ring symptoms with red margins (Fig. 2A), as observed by Rossel and Thottapilly (28), who were the first to detect this virus in Taiwan, but similar symptoms may be caused by other viruses. Plants infected with SPFMV alone also sometimes developed rings (Fig. 2B), but they were always less distinct than those in plants infected with SPV2. SPFMV was found to infect sweetpotato plants from all three collection locations in Western Australia and in all four of the named sweetpotato cultivars tested. SPV2 was less common, as it was only detected in one lot of roots of cv. Northern Star from a supermarket in Perth and in a crop of cv. Jewel in the field in Broome. Although these two locations are very distant from each other, all the SPV2 isolates were nearly identical in their CP-encoding regions and, hence, belong to the same genetic strain, in contrast to the SPFMV isolates that were readily distinguishable to strains RC and C $(22,34)$. The finding of only two viruses, SPFMV and SPV2, in

Table 4. Percent nucleotide (543 nt, above diagonal) and amino acid (181 aa, below diagonal) sequence identity of the N-proximal CP-encoding sequences of Sweet potato virus 2 (SPV2) isolates

\begin{tabular}{|c|c|c|c|c|c|c|c|c|c|c|c|c|c|c|c|c|c|c|c|c|c|c|c|}
\hline SN & Isolate & Origin & 1 & 2 & 3 & 4 & 5 & 6 & 7 & 8 & 9 & 10 & 11 & 12 & 13 & 14 & 15 & 16 & 17 & 18 & 19 & 20 & 21 \\
\hline 1 & Aus54 & Australia & $* * *$ & 99.6 & 99.8 & 99.6 & 99.4 & 98.7 & 99.1 & 97.2 & 97.2 & 97.8 & 95.4 & 95.2 & 91.2 & 94.7 & 96.9 & 84.3 & 91.2 & 96.3 & 97.6 & 76.4 & \\
\hline 2 & Aus55-4 & & 98.9 & $* * *$ & 99.8 & & 99.4 & 98.7 & 9.1 & & 7.2 & & 5.4 & & & 4.7 & 6.9 & & 1.2 & 6.3 & & 6.4 & 4.8 \\
\hline 3 & & & 9.4 & 99.4 & $* * *$ & 99.8 & 99.6 & 98.9 & 9.3 & & & & 5.6 & & & & 7.1 & 4.5 & 1.3 & 6.5 & & 6.6 & 5.0 \\
\hline 4 & 1 & & 8.9 & 8.9 & 99.4 & $* * *$ & 99.4 & 98.7 & 99.1 & 7.2 & 97.2 & 7.8 & 5.4 & 95.2 & & 4.7 & 6.9 & 84.3 & 1.2 & 6.3 & 7.6 & 6.8 & 65.7 \\
\hline 5 & & & 8.9 & 8.9 & 99.4 & 98.9 & $* * *$ & 98.5 & 98.9 & & 97.1 & 7.6 & 5.2 & 95.0 & & & 6.7 & 4.2 & 1.0 & 6.1 & 7.4 & 6.4 & 5.6 \\
\hline 6 & & & 97.8 & 97.8 & 98.3 & 97.8 & 97.8 & $* * *$ & 98.9 & & 97.1 & 7.6 & 95.4 & 95.2 & 0.2 & 4.7 & 96.7 & 84.0 & 90.2 & 6.5 & 7.4 & 6.6 & 65.0 \\
\hline 7 & & & 8.3 & 8.3 & 98.9 & & 98.3 & 98.3 & $* * *$ & & & & 5.6 & & & & & 4.2 & & 6.5 & & & 4.8 \\
\hline 8 & Lol & & 96.1 & 96.1 & 96.7 & 96.1 & 96.1 & 95.6 & 96.1 & $* * *$ & 100.0 & 99.1 & 95.9 & 96.1 & 91.0 & 5.6 & 97.4 & 84.9 & 91.0 & 96.9 & 8.2 & 7.0 & 65.0 \\
\hline 9 & & & 6.7 & 6.7 & 97.2 & & 96.7 & 96.1 & 96.7 & & & & 5.9 & & & & 7.4 & & & .9 & & & 5.0 \\
\hline 10 & 3009 & & 96.1 & 96.1 & 96.7 & 96.1 & 96.1 & 95.6 & 96.1 & 10 & 9.4 & $* * *$ & 96.5 & 96.3 & 91.5 & 5.8 & 98.0 & 85.6 & 91.5 & 97.4 & 8.7 & 76.8 & 65.9 \\
\hline 11 & & & 1.7 & 1.7 & 92.3 & & 91.7 & 91.2 & 91.7 & & 3.4 & 92.8 & $* * *$ & 98.0 & & & 5.6 & 4.3 & 9.5 & 5.0 & 6.3 & 6.1 & 4.8 \\
\hline 12 & & & 90.6 & 0.6 & 91.2 & 5 & 90.6 & 90.1 & 90.6 & 3 & 2.8 & 92.3 & 87.8 & $* * *$ & 89.1 & 98.7 & 95.4 & 85.1 & 89.1 & 94.8 & 6.1 & 76.1 & 64.5 \\
\hline 13 & & & 92.3 & 2.3 & 92.8 & 92.3 & 92.3 & 91.7 & 92.3 & 4 & 93.9 & 93.4 & 96.1 & 89.0 & & 88.6 & 1.5 & 2.9 & 9.4 & 1.2 & 1.9 & 4.6 & 65.7 \\
\hline 14 & & & 95.6 & 5.6 & 96.1 & & 95.6 & 95.0 & 95.6 & 2 & 7.8 & 97.2 & 92.3 & 94.5 & & $* * *$ & 94.8 & 84.9 & 6 & 94.7 & & 75.7 & 65.0 \\
\hline 15 & sch & & 90.6 & 0.6 & 91.2 & 90.6 & 90.6 & 90.1 & 90.6 & 7 & 92.3 & 91.7 & 92.3 & 89.5 & 4 & 91.2 & $* * *$ & 84.5 & 1.5 & 6.5 & 7.8 & 6.6 & 65.7 \\
\hline 16 & Thom & rica & 90.6 & 90.6 & 91.2 & 90.6 & 90.6 & 90.1 & 90.6 & 92.8 & 93.4 & 92.8 & 87.8 & 98.3 & 88.4 & 94.5 & 89.5 & $* * *$ & 82.9 & 83.8 & 5.6 & 5.7 & 64.1 \\
\hline 17 & VTSBTs & & 92.8 & 2.8 & 93.4 & 92.8 & 92.8 & 92.3 & 92.8 & 93 & & 93.9 & 96.7 & 89.0 & & & 3.9 & & $* * *$ & 91.2 & 2.1 & 4.4 & 65.7 \\
\hline 18 & Nigeria & frica & 95.0 & 5.0 & 95.6 & 95.0 & 95.0 & 94.5 & 95.0 & 96. & 97.2 & 96.7 & 91.7 & 92.3 & 92.3 & 96.1 & 90.6 & 92.3 & 92.8 & $* * *$ & 97.2 & 75.0 & 66.5 \\
\hline 19 & XN3 & & 96.1 & 96.1 & 96.7 & 96. & 96.1 & 95.6 & 96.1 & 97.8 & 98.3 & 97.8 & 92.8 & 92.8 & & 97.2 & 92.3 & 92.8 & 93.9 & 96.7 & $* * *$ & 76.6 & 65.6 \\
\hline 20 & Zambia & & 78.5 & 78.5 & 79.0 & 79.6 & 78.5 & 79.6 & 79.0 & 79.6 & 80.1 & 79.6 & 77.9 & 77.9 & 77.9 & 79.6 & 76.8 & 77.9 & 77.9 & 79.0 & 9.0 & $* * *$ & 64.5 \\
\hline 21 & SPFMV & Zimbabwe & 54.7 & 54.7 & 55.2 & 55.2 & 55.2 & 55.8 & 54.7 & 56.9 & 56.9 & 56.9 & 60.2 & 60.2 & 59.7 & 60.2 & 58.0 & 60.2 & 59.7 & 59.1 & 55.8 & 58.0 & $* * *$ \\
\hline
\end{tabular}


our survey based on serological testing for 11 different sweetpotato viruses, is consistent with the very recent introduction of cultivated plants to Australia, where there were none until European colonization 200 years ago. Many viral pathogens of crop plants have not yet reached this isolated island continent, which adopts a strict plant quarantine policy. By contrast, in countries with a longer history of cultivation, sweetpotato is usually infected with many more viruses $(8,23,34)$.

Phylogenetic analysis of partial SPV2 $\mathrm{CP}$-encoding sequences showed that the Australian isolates formed a group that was distinguishable from isolates from Asia, Africa, Europe, and the United States. However, the two SPV2 isolates described in the United States (32) were closest to the SPV2 isolates from Australia. SPV2 is the second sweetpotatoinfecting potyvirus, after SPFMV (34), for which enough isolates (a total of 21) have been partially sequenced and sufficient data available from databanks justifies such an analysis. These data largely originate from the work of E. M. Ateka, E.
Barg, R. W. Njeru, and H. J. Vetten (Table 3). Our results suggest that SPV2 isolates form at least three distinct phylogenetic groups, but a few isolates could not be placed within any of them. Only strain EA of SPFMV is largely restricted geographically to East Africa, the other strains being distributed worldwide (34). The Australian isolates of SPV2 grouped together, in accordance with their geographic origin, but the other two phylogenetic groups contained isolates from more than one continent. We do not suggest that the Australian SPV2 group originated in this continent, however, as the crop has a very recent history of cultivation ( $<200$ years).

Our study revealed that SPFMV-C is common in sweetpotato in Australia, where it co-infects with RC and SPV2. As mentioned above, SPFMV-C could not be detected with antibodies currently available from CIP or BBA, Braunschweig. As these antibodies have been widely used for virus indexing in sweetpotato, the prevalence of SPFMV-C in sweetpotato crops may be much higher than previously realized $(25,34)$. Although the primers we used allow specific detection of SPFMV-C and SPV2, it was considered important to establish a detection system that could reveal and identify all the three locally prevailing sweetpotato viruses and strains simultaneously. Restriction with $P v u \mathrm{II}$ of the $1.8-\mathrm{kb}$ amplicons obtained with universal (degenerate) primers from all these viruses resulted in a $1.4-\mathrm{kb}$ and a $1.3-\mathrm{kb}$ restriction fragment diagnostic to SPFMV-C and SPV2, respectively. In contrast, the HindIII restriction site in the amplicon of SPFMVRC differentiated it from SPFMV-C and SPV2. We also showed that HindIII cleaves the amplicons of SPFMV strains $\mathrm{RC}$ and EA similarly, but these strains are differentiated by EcoRI restriction since there is no recognizable restriction site for this endonuclease in the amplicon of EA.

The widespread occurrence of SPFMV and SPV2 in Australian sweetpotato crops in our survey suggests that to provide a reliable virus-free stock program, tests for specific viruses on sweetpotato samples should be supplemental to indexing by grafting. Although in this study, RT-PCRbased virus detection was from total RNA

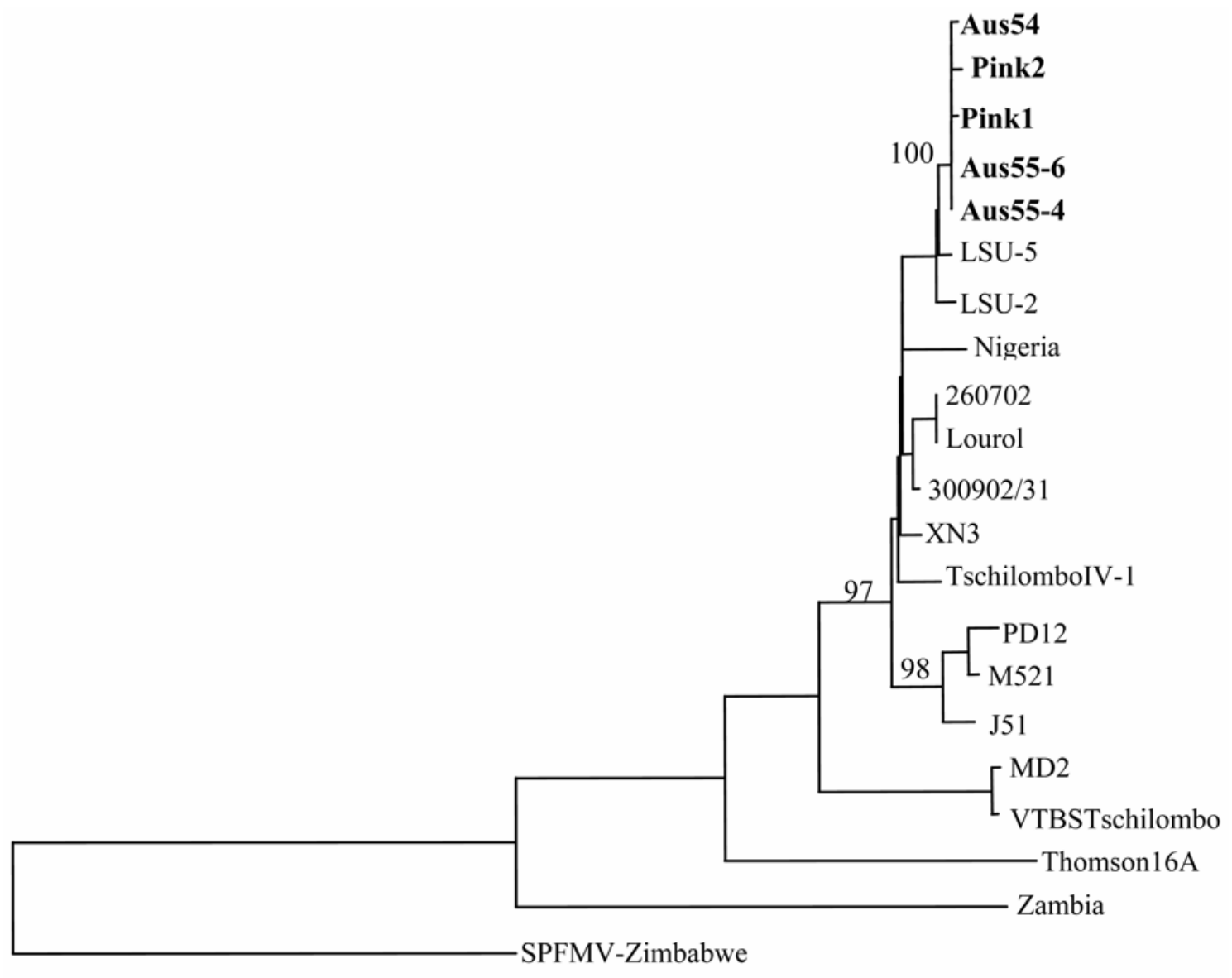

Fig. 3. Phylogenetic analysis of the partial coat protein encoding sequences (N-proximal 543 nucleotides) of Sweet potato virus 2 (SPV2). Isolates Aus54, Aus55-4, Aus55-6, Pink1, and Pink2 from Australia (in bold) were characterized in this study. The other sequences were from the EMBL sequence databank (Table 3). Isolates LSU-2 and LSU-5 are from the United States; 260702, 300902/31, and Lourol are from Portugal; one isolate each originate in Nigeria (Nigeria), Zambia (Zambia), and China (XN3); and the remaining isolates are from South Africa. Sweet potato feathery mottle virus (SPFMV), isolate Zimbabwe (AF015541) from Chavi et al. (6), which is only distantly related to SPFMV and other potyviruses infecting sweetpotato $(4,26,32)$, was used as an outgroup. Bar indicates genetic distance (0.1 units; 21). 
extracted directly from sweetpotato, in our experience, the nucleic acid extracts from sweetpotato leaves contain enzyme inhibitors that can hamper RT and/or PCR, regardless of the method of RNA extraction. Indeed, virus detection by RT-PCR is more reliable from leaves of the indicator plant I. setosa. Consequently, the virus indexing scheme used during healthy stock propagation would involve testing the I. setosa scions graft-inoculated to the mother plants, thereby ensuring that any asymptomatic infections with SPFMV are captured.

\section{ACKNOWLEDGMENTS}

In addition to those mentioned in the text who supplied virus-specific antibodies, we thank Eva Gajda for help in propagating sweetpotato, Tracey Smith for serological tests, and Alois Kullaya, Settumba Mukasa, and Anders Kvarnheden for helpful advice. This study was supported financially by the Department of Agriculture for Western Australia, Murdoch University (which funded sample collection in the Kimberley region), Academy of Finland (grant 1102134), and the East African Regional Programme and Research Network for Biotechnology, Biosafety and Biotechnology Policy Development (BIOEARN, www.bio-earn.org; project no. 771402) funded by Sida/SAREC through the Stockholm Environmental Institute (SEI).

\begin{tabular}{|l|c|c|}
\hline \multirow{2}{*}{ Virus } & \multicolumn{2}{|c|}{ Restriction pattern } \\
\cline { 2 - 3 } & HindIII & $P v u I I$ \\
\hline SPFMV-RC & $1.3 / 0.5 \mathrm{~kb}$ & uncut \\
\hline SPFMV-C & uncut & $1.4 / 0.4 \mathrm{~kb}$ \\
\hline SPV2 & uncut & $1.3 / 0.5 \mathrm{~kb}$ \\
\hline
\end{tabular}

\section{RT-PCR}
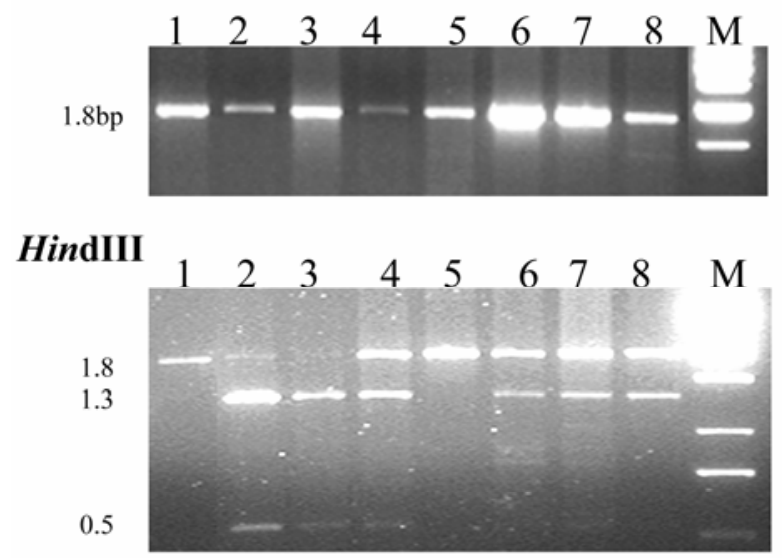

\section{PvuII}

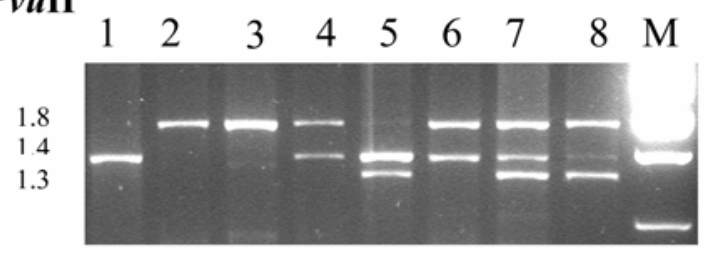

\section{Interpretation}

\begin{tabular}{|l|c|c|c|c|c|c|c|c|}
\hline & $\mathbf{1}$ & $\mathbf{2}$ & $\mathbf{3}$ & $\mathbf{4}$ & $\mathbf{5}$ & $\mathbf{6}$ & $\mathbf{7}$ & $\mathbf{8}$ \\
\hline SPFMV-RC & & + & + & + & & + & + & + \\
\hline SPFMV-C & + & & & + & + & + & + & + \\
\hline SPV2 & & & & & + & & + & + \\
\hline
\end{tabular}

Fig. 4. Molecular resolution of potyviral complexes in sweetpotato plants using restriction analysis of reverse transcription-polymerase chain reaction (RT-PCR) amplicons. Restriction patterns for Sweet potato feathery mottle virus strains RC (SPFMV-RC) and C (SPFMV-C) and Sweet potato virus 2 (SPV2) were predicted by computer-based analysis of sequences from this study and those available from databases. The $3^{\prime}$ end (ca. $1.8 \mathrm{~kb}$ ) of the viral genome was amplified (panel "RT-PCR"), the products were treated with HindIII or PvuII, and restriction fragments were separated by agarose gel electrophoresis. Interpretation of the data is shown at the bottom. The sample in each lane corresponds to a different, naturally infected sweetpotato plant. Note that the restriction fragment diagnostic to SPFMV-C following cleavage with $P v u I I$ is only weakly visible in plant 8 (lane 8 ). The larger, diagnostic restriction fragments generated by $P v u \mathrm{II}$ are shown. M, DNA size markers (MBI Fermentas) (see panel "HindIII" for the 1.88, 1.49, 1.15, 0.93, and $0.42 \mathrm{~kb}$ size markers; large markers are not well-separated due to a short gel running time). Sizes of the RT-PCR product and diagnostic restriction fragments are indicated to the left.

\section{LITERATURE CITED}

1. Abad J. A., Conkling, M. A., and Moyer, J. W. 1992. Comparison of the capsid protein cistron from serologically distinct strains of sweet potato feathery mottle virus (SPFMV). Arch. Virol. 126:147-157.

2. Adams, M. J., Antoniw, J. F., and Beaudoin, F. 2005. Overview and analysis of the polyprotein cleavage sites in the family Potyviridae. Mol. Plant Pathol. 6:471-487.

3. Ateka, E. M., Barg, E., Njeru, R. W., Lesemann, D. E., and Vetten, H. J. 2004. Further characterization of 'sweet potato virus 2': A distinct species in the genus Potyvirus. Arch. Virol. 149:225-239.

4. Ateka, E. M., Njeru, R. W., Kibaru, A. G., Kimenju, J. W., Barg, E., Gibson, R. W., and Vetten, H. J. 2004. Identification and distribution of viruses infecting sweet potato in Kenya. Ann. Appl. Biol. 144:371-379.

5. Brunt, A., Crabtree, K., and Gibbs, A. 1990 Viruses of Tropical Plants: Descriptions and Lists from the VIDE Database. CAB International, Wallingford, UK.

6. Chavi, F., Robertson, A. I., and Verduin, B. J. M. 1997. Survey and characterization of viruses in sweetpotato from Zimbabwe. Plant Dis. 81:1115-1122.

7. Chen, J., Chen, J., and Adams, M. J. 2001. A universal PCR primer to detect members of the Potyviridae and its use to examine the taxonomic status of several members of the family. Arch. Virol. 146:757-766.

8. Clark, C. A., and Hoy, M. W. 2006. Effects of common viruses on yield and quality of Beauregard sweetpotato in Louisiana. Plant Dis. 90:83-88.

9. Colinet, D., Nguyen, M., Kummert, J., and Lepoivre, P. 1998. Differentiation among potyviruses infecting sweet potato based on genus- and virus-specific reverse transcription polymerase chain reaction. Plant Dis. 82:223229.

10. Di Feo, L., Nome, S. F., Biderbost, E., Fuentes, S., and Salazar, L. F. 2000. Etiology of sweet potato chlorotic dwarf disease in Argentina. Plant Dis. 84:35-39.

11. Fauquet, C. M., Mayo, M. A., Maniloff, J. Desselberger, U., and Ball, L. A. 2005. Virus Taxonomy. Eighth Report of the International Committee on Taxonomy of Viruses. Elsevier, San Diego, CA.

12. Gibb, K. S., and Padovan, A. C. 1993. Detection of Sweet potato feathery mottle virus in sweet potato grown in Northern Australia using an efficient and simple assay. Intern. J. Pest Manag. 39:223-228.

13. Gibbs, A., and Mackenzie, A. 1997. A primer pair for amplifying part of the genome of all potyvirids by RT-PCR. J. Virol. Methods 63:916.

14. Gibson, R. W., Mpembe, I., Alicai, T., Carey, E. E., Mwanga, R. O. M., Seal, S. E., and Vetten, H. J. 1998. Symptoms, aetiology and serological analysis of sweet potato virus disease in Uganda. Plant Pathol. 47:95-102.

15. Heisswolf, S., Galea, V. J., and Persley, D. M. 1994. A preliminary assessment of sweet potato cultivars for Sweet potato feathery mottle virus (SPFMV). Aust. Plant Pathol. 23:77-80.

16. Hoyer, U., Maiss, E., Jelkmann, W., Lesemann, D.-E., and Vetten, H. J. 1996. Identification of the coat protein gene of a sweet potato sunken vein closterovirus isolate from Kenya and evidence for a serological relationship among geographically diverse closterovirus isolates from sweet potato. Phytopathology 86:744-750.

17. IsHak, J. A., Kreuze, J. F., Johansson, A., Mukasa, S. B., Tairo, F., Abo El-Abbas, F. M., and Valkonen, J. P. T. 2003. Some molecular characteristics of three viruses in sweet potato virus disease-affected sweet potato plants in 
Egypt. Arch. Virol. 148:2449-2460.

18. Karyeija, R. F., Gibson, R. W., and Valkonen, J. P. T. 1998. The significance of sweet potato feathery mottle virus in subsistence sweet potato production in Africa. Plant Dis. 82:4-15.

19. Karyeija, R. F., Gibson, R. W., and Valkonen, J. P. T. 2000. Synergistic imteractions of a potyvirus and a phloem-limited crinivirus in sweetpotato cultivars. Virology 269:26-36.

20. Karyeija, R. F., Kreuze, J. F., Gibson, R. W., and Valkonen, J. P. T. 2000. Two serotypes of Sweetpotato feathery mottle virus in Uganda and their interaction with resistant sweetpotato cultivars. Phytopathology 90:1250-1255.

21. Kimura, M. 1980. A simple method of estimating evolutionary rates of base substitution through comparative studies of nucleotide sequences. J. Mol. Evol. 16:111-120.

22. Kreuze, J. F., Karyeija, R. F., Gibson, R. W., and Valkonen, J. P. T. 2000. Comparisons of coat protein gene sequences show that East African isolates of Sweet potato feathery mottle virus form a genetically distinct group. Arch. Virol. 145:567-574.

23. Loebenstein, G., Fuentes, S., Cohen, J., and Salazar, L. F. 2003. Sweet potato. Pages 223248 in: Viruses and Virus-Like Diseases of Major Crops in Developing Countries. G. Loebenstein and G. Thottapilly, eds. Kluwer Aca- demic Publishers, Dortrecht, The Netherlands.

24. Moyer, J. W., Cali, B. B., Kennedy, G. G., and Abu-Ghadir, M. F. 1980. Identification of sweet potato feathery mottle virus strains in North Carolina. Plant Dis. 64:762-764.

25. Mukasa, S. B., Rubaihayo, P. R., and Valkonen, J. P. T. 2003. Incidence of viruses and viruslike diseases of sweetpotato in Uganda. Plant Dis. 87:329-335.

26. Mukasa, S. B., Tairo, F., Kullaya, A., Rubaihayo, P. R., and Valkonen, J. P. T. 2003. Coat protein sequence analysis reveals occurrence of new strains of sweet potato feathery mottle virus in Uganda and Tanzania. Virus Genes 27:49-56.

27. Nome, S. F. 1973. Sweetpotato vein mosaic in Argentina. Phytopathol. Z. 77:44-45.

28. Rossel, H. W., and Thottappilly, G. 1988. Complex virus diseases of sweet potato. Pages 291-302 in: Exploration, Maintenance and Utilisation of Sweet Potato Genetic Resources. Report of first Sweet Potato planning Conference 1987. International Potato Centre, Lima, Peru.

29. Sakai, J., Mori, M., Morishita, T., Tanaka, M., Hanada, K., Usugi, T., and Nishiguchi, M. 1997. Complete nucleotide sequence and genome organization of sweet potato feathery mottle virus (S strain) genomic RNA: the large coding region of the P1 gene. Arch. Virol 142:1553-1562.

30. Sambrook, J., Fritch, E. E., and Maniatis, T. 1989. Molecular Cloning: A Laboratory Manual. 2nd ed. Cold Spring Harbor Laboratory, Cold Spring Harbor, NY.

31. Shukla, D. D., Ward, C. W., and Brunt, A. A 1994. The Potyviridae. CAB International, Littlehampton, UK.

32. Souto, E. R., Sim, J., Chen, J., Valverde, R. A., and Clark, C. A. 2003. Properties of strains of Sweet potato feathery mottle virus and two newly recognized potyviruses infecting sweet potato in the United States. Plant Dis. 87:1226 1232.

33. Tairo, F., Kullaya, A., and Valkonen, J. P. T. 2004. Incidence of viruses infecting sweetpotato in Tanzania. Plant Dis. 88:916-920.

34. Tairo, F., Mukasa, S. B., Jones, R. A. C., Kullaya, A., Rubaihayo, P. R., and Valkonen, J. P. T. 2005. Unraveling the genetic diversity of the three main viruses involved in Sweet Potato Virus Disease (SPVD) and its implications. Mol. Plant Pathol. 6:199-211.

35. Zhang, D., Rossel, G., Kriegner, A., and Hijmans, R. 2004. AFLP assessment of diversity in sweetpotato from Latin America and the Pacific region: Its implications of the dispersal of the crop. Genet. Res. Crop Evol. 51:115-120. 